\title{
Journalism in transition in front of the V IPCC Report, the Paris agreement and the sustainable development goals
}

institucional.us.es/ambitos/

\section{Rogelio Fernández Reyes}

Grupo de Investigación GREHCCO (Universidad de Sevilla) y Grupo de Investigación MDCS (Universidad Complutense de Madrid)

\section{Juan Carlos Águila Coghlan \\ Grupo de Investigación MDCS (Universidad Complutense de Madrid)}

Spanish Version: Un periodismo en transicion ante el V informe del IPCC, El acuerdo de París y Los objetivos de desarrollo sostenible.

The Intergovernmental Panel on Climate Change (IPCC) recognizes that climate change is clear, unequivocal, has already generated impacts on all continents and oceans, and mitigation and adaptation will be necessary to avoid harmful climatic impacts (IPCC 2014). The Sustainable Development Goals have climate change as one of the main challenges. The Paris Agreement (2015) has set itself the goal of "keeping the average global temperature rise well below $2^{\circ} \mathrm{C}$ above pre-industrial levels and continuing efforts to limit that temperature rise to $1,5^{\circ} \mathrm{C}$ ". The IPCC indicates that there is little time left to prevent the average temperature rises above $2^{\circ} \mathrm{C}$ from pre-industrial levels. In this essay, it is considered that in order to achieve -

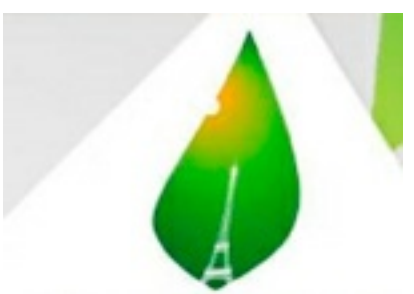
PARIS2015 UN CUMATE CHANGE CONFERENCE or approach- the objective of increasing the temperature not to exceed $1.5^{\circ} \mathrm{C}$, a transformational change, that is, systemic, must take place over a short period of time. It is proposed to reflect on how to seek journalism in transition that, without renouncing rigor and objectivity, places sustainability as a reference axis. And we reflect on what elements may be interesting in communicative practices before the $\mathrm{V}$ IPCC Report, the Sustainable Development Goals and the Paris Agreement.

Keywords: Media, Transition Journalism, Climate Change, Paris Agreement, Sustainable Development Goals.

\section{Introduction}

We are in an exceptional historical moment facing the reality of global change [01], a challenge of a great dimension that requires a great response. Global change shows that the human being is modifying the relative stability of the biosphere of the last thousands of years and forcing its natural variability. The growth of the overshoot of the human species at several environmental thresholds (Rockström et al, 2009) leads to an increase in the imbalance in the biosphere in the present stage of the Anthropocene (Crutzen and Stoermer, 2000). Today, climate change [02] is a manifestation of this global change, called to be its main engine, increasingly determining the alteration of the functioning and services of terrestrial ecosystems worldwide (Duarte, 2006: 93).

The Stockholm Memorandum (2011), signed by some 20 Nobel laureates, recognized the human being as the main cause of climate change, whose collective actions can have irreversible consequences for the planet. "We can not go this way and we need to get in quick action," concluded the Nobel laureate in Chemistry, Mario Molina. The transition to other sustainable forms of life "poses an exercise of profound revision on the historical moment in which we find ourselves requiring a worldview different from the one that has brought us to the crisis", explains María Novo (2016: 233).

As a counterpoint to the overreaching that part of humanity is exercising is the commitment to a transition [03] that gives the leading role to sustainability, within a framework of complex adaptive systems. It is a question of 
regressing in the transgressed limits, avoid crossing more limits, or minimizing the effects of the thresholds shifted, that allows the new generations and the rest of the species to be able to enjoy the minimum disturbed Earth system with respect to the last thousands of years. We consider that a deceleration, a material and energetic decrease in part of the population of the planet is necessary to grow in humanity, accepting the limits of the growth, complex reality in the distribution of available resources and the responsibility of the current situation.

The journalistic practice reflects and participates (Rojo and Maestre, 2005) in the social representation of sustainability and in the contribution of solutions. Media, therefore, unhurried or facilitate the approach of a cultural change as we understand it is required. This essay is a summary update, accompanied by new contents, of the article "In search of journalism in transition" (Fernández-Reyes, 2016b). It sought to justify the need for a systemic change in the journalistic exercise and addressed some functions and dysfunctions of journalism around sustainability.

It is destined to professionals and students of the journalistic profession, as well as to communication researchers interested in the reaction against the excess of the human being in the biosphere. It does not pretend to convince but to reflect on the quest for journalism in transition and perhaps to make it easier for others to find their own conclusions on the crucial challenge we face. For many contexts it may be impossible or utopian. But, $¿$ is it not more utopian to think that we can continue with the dynamics of endless growth without ending in a collapse, an implosion of the present civilization?

We will focus mainly on the analysis of elements of transition in the field of journalistic content. The limitations prevent us from addressing such important elements as journalistic structures or the reality of the profession and professionals, which will be essential to study. We will focus specifically on the objective of reacting to the temperature increase agreed in the Paris Agreement (COP 21), based on the scientific basis of the V IPCC Report, in line with the Sustainable Development Objectives.

\section{The V IPCC Report, the Paris Agreement and the Sustainable Development Objectives in the paradigm of growth}

The Fifth Report of the UN Intergovernmental Panel on Climate Change (IPCC, 2013-2014) confirms a series of conclusions regarding the reality of climate change, its causes, its consequences and its solutions: a) "Warming of the climate system is unequivocal "(IPCC, 2013: 4); b) "The human influence on the climate system is clear" (IPCC, 2013: 15); c) "Climate change in the last decades has caused impacts on natural and human systems in all continents and oceans" (IPCC, 2014a: 4); d) "Global society will have to mitigate and adapt to climate change if it is to effectively prevent harmful climatic impacts" (IPCC, 2014b)

The Paris Agreement (2015) stated that it pursued the climate objective of "keeping the average global temperature rise well below $2^{\circ} \mathrm{C}$ above pre-industrial levels and continuing efforts to limit that temperature rise to $1.5^{\circ} \mathrm{C}$. What would it mean for all States to keep their promises and to honor the commitments made in Paris? Christiana Figueres, Executive Secretary of the UNFCCC [04], referred to $2.7^{\circ} \mathrm{C}$ as a figure that would accompany the fulfillment of national promises (UNFCCC, 2015). But if we take into account other studies of nationally determined contributions (INDCs), the result is a fork between 2.7 and $3.7^{\circ} \mathrm{C}$. But if we take into account other studies of nationally determined contributions (INDCs), the result is a fork between 2.7 and $3.7^{\circ}$ C. [05]

In September 2015, representatives of 193 countries adopted a historic commitment to approve the 17 Sustainable Development Goals. The UN, on its website, focused these goals on "eradicating poverty, protecting the planet and ensuring sustainability" [06]. The UN Millennium Development Goals (2000-2015) went from having 1 objective (of 8) related to sustainability to having in the objectives of sustainable development (20152030) 11 objectives (of 17) in which makes reference to the term sustainable, to which must be added its presence in the title and a specific objective on the challenge before us: "Take urgent measures to combat climate change and its effects".

In what paradigm is the V IPCC Report, the Paris Agreement and the Sustainable Development Objectives 
framed? In the paradigm of growth. The V IPCC Report identifies two main drivers of climate change: economic growth and population growth (IPCC, 2014c: 5). Is it possible to address climate change without going to the roots, without changing the prevailing economic model and demographic trends?

The IPCC works on the requirements of the countries and these do not pose premises that compromise the development (eg: IPCC, 2014b: 20). Scientists do not include scenarios of material decay in the countries with the greatest impact on Earth. Is an urgent change in climate governance possible without compromising development? [07] We understand that development must meet social needs within the limits imposed by the biosphere. To consider that the biosphere has to satisfy the needs of the human being within the limits imposed by development is part of a limited anthropocentric, exclusionary and short-stance attitude, which ends up turning against its legitimate aspiration [08].

The most suggestive content of the Paris Agreement is found in the preamble, which lacks legal force. It recognizes that climate change is "a pressing threat and have potentially irreversible effects for human societies and the planet," which "will require strong reductions in global emissions" and the "urgency" to address them. However, the Agreement itself does not present a substantial change. It was limited by strong political and economic interests, which removed the term decarbonization, within a framework of unquestioned economic growth. For that reason it went from the figure of Protocol to the Agreement, which reduced the international legal force of the text (Fernández-Reyes, 2016a). Growth remains an indisputable premise in the Sustainable Development Goals.

The neoliberal hegemonic model of production and consumption is not questioned (Meira, 2015: 58). As Professor Meira points out from the socio-environmental perspective, the problem is not the accuracy of the defined objectives or the possibility of their fulfillment in the estimated time edges, as in the model of development that it frames. It is considered that "without growth, it will not be possible to eradicate poverty and generate well-being, nor to release sufficient resources -technological, cultural, economic- to achieve sustainable management of the biosphere. Growth appears, therefore, as a sine qua non condition of development and sustainability" (p. 59).

Edgar Morin argues that the idea of development is an underdeveloped idea (Morin, 2011: 27). As the French philosopher and sociologist, the fixed idea of growth, puts forward, "should not it be replaced by a complex concept involving various growths, decreases and stabilizations? (p. 25).

And what are the probabilities of remaining in an overall average increase of " $1.5^{\circ} \mathrm{C}$ " or "well below $2^{\circ} \mathrm{C}$ "? From the scientific point of view, it is considered that if there is no drastic quantification of emissions by 2050 , the objectives of temperature increases "below $2^{\circ} \mathrm{C}$ " or " $1.5^{\circ} \mathrm{C}$ " is a voluntary exercise [09]. You should reach the emission peak in 2020 to ensure that the increase does not exceed " $1.5^{\circ} \mathrm{C}$ "! Given these climate objectives, what kind of change is needed?

\section{Journalism in transition facing the V IPCC Report, the Paris Agreement and the Sustainable Development Objectives}

The Synthesis Report The environment in Europe. State and prospects 2015, of the European Environment Agency (EEA) included:

"Living well without exceeding ecological limits requires fundamental transitions in production and consumption systems, the ultimate responsibility for environmental and climatic pressures. The very nature of these transitions will require major changes in institutions, practices, technologies, policies, lifestyles and prevailing thinking" ( $p$. 14).

Today, it is possible to affirm that the mediatic virtuality is far from biophysical reality. Media can cut this distance or encourage it. The search for journalism in transition is considered as a voluntary option -which can become involuntarily forced if we cross climatic edges that cause changes on a large scale- a civic commitment in front to the imbalance that is being generated by the human being in the biosphere. It is an interpretation and at the 
same time a proposal that starts from the consideration that the situation of overshoot of the climatic change requires a cultural change, that in turn demands a media change.

Journalism in transition could be defined as the theoretical perception and journalistic exercise that, faced with global change, and mainly climate change, opts for a cultural change in which sustainability is prioritized as the axis. It is assumed as a social function of the media and a legitimate requirement of society. It is justified by the care of the human species and future generations, and the care of the rest of the species and ecosystems, considering that the other species have a per se value.

Faced with the challenge of climate change, the journalism in transition starts from that is the excessive concentration of greenhouse gases [10] and its relation with the increase of temperature, now shown with robustness from the scientific field. The point of arrival is the brake and shrinking in the concentration of $\mathrm{CO} 2-e q$ in the atmosphere and in the increase of the temperature. Specifically, the objective of a temperature increase well below $2^{\circ} \mathrm{C}$, pursuing it does not exceed $1.5^{\circ} \mathrm{C}$.

Next, some points are suggested that may be of interest in the search for journalism in transition on the approach of the communication of climate change and the alternatives after the results of the V IPCC Report, the Paris Agreement and the Objectives of Sustainable Development.

\section{a) A greater and better quantitative and qualitative treatment}

If climate change has become a priority issue on the international agenda in Paris, with the greatest historical arrival of heads of State, a better media treatment is opportune [11]: facilitating debate, making citizen mobilization, alternative experiences [12], signs of will and political practice, recognition of the real dimension of the problem, pronouncement of leaders from different fields, initiatives of common commitment, successive scientific reports. It is unjustified that the proportion of the media presence of climate change is not parallel to scientific robustness and risk perception:

Coverage in the Spanish press of the terms climate change or global warming (January 2000-May 2017): data by head and total

\section{0-2017 Spain Newspaper Coverage of Climate Change or Global Warming}

\section{Click and drag in the plot area to zoom in}

800

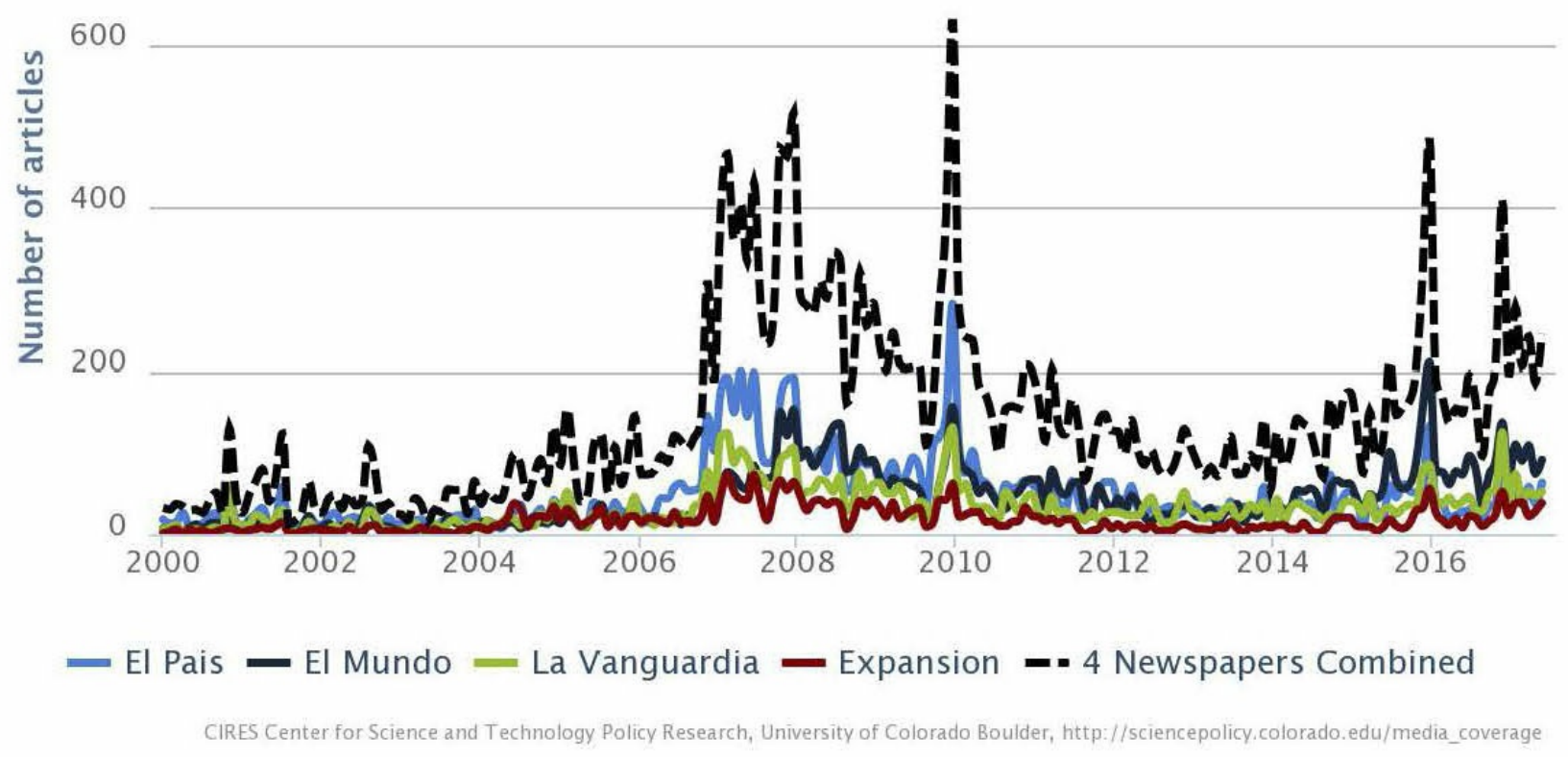


Graph 1: Fernández-Reyes, Rogelio 2017 Spain Newspaper Coverage of Climate Change or Global Warming, 2000-2017. Universidad de Sevilla. http://sciencepolicy.colorado.edu/media_coverage/spain. [access on June 16, 2017]

As for the qualitative treatment, it may be appropriate to take into account that the journalistic accounts on climate change are different if they are elaborated from a productivist paradigm that if they are elaborated from an ecological paradigm. This calls into question the alleged asepsis. These differences can be perceived, among other elements, in: greater or lesser coverage of a topic, selection of actors (institutions, experts and counterexperts), arguments (in which reality is interpreted and constructed), proposal for action (actions or inaction fields), the attribution of responsibilities, the recognition of consequences, the degree of recognition or questioning of scientific claims or of different sources (Fernández-Reyes, 2010: 16b). It would be opportune to advance in the integration of the ecological paradigm when elaborating the stories.

\section{b) Link the climate objective with reduction and decarbonization.}

The debate on the climate objective should not replace what is really important, which is the reduction of emissions (Boykoff et al, 2010). The reduction of the climatic target in the Paris Agreement from $2^{\circ}$ to $1,5^{\circ} \mathrm{C}$ has been an achievement of the citizen and political mobilization, directly linked to the term "decarbonization". The IPCC Report V clearly states that to mitigate climate change, it will be necessary to decarbonise the energy sector [13]. In addition to being a term used in the V IPCC Report, the UN included it in drafts of the Paris Summit, but was removed by the influence of oil producing countries. In the end, resulted in the term "balance" in the Paris Agreement, based on carbon sequestration and storage mechanisms. [14]

In view of this, we consider that the use and practice of the term "decarbonisation" cannot be abandoned in order to achieve the temperature target agreed upon in Paris. A low carbon culture is inevitably confronted with business, political and social interests around fossil fuels. Even with the consumer habits of life addicted to carbon, which will have to go through a detoxification. And it is imperative to introduce the debate on measures for maritime and air transport, removed from the drafts of the Agreement. These are two of the sectors with the highest emissions: $10 \%$ of global emissions.

\section{c) Linking Climate Change to Migration Flows}

One of the consequences of climate change is migration. It is an issue that is still under-researched and little visible that has a great interest (Rivillo, 2015). While migration flows cannot be attributed to climate change exclusively, it can be argued that, increasingly, climate change is a key factor in population mobilizations. Extreme weather events displaced 184 million people between 2008 and 2014 [15].

The ethical framework and the value of the common good favor the treatment of this subject. It should not be forgotten that nations and citizens with low emission production suffer and will suffer the most the impact produced by nations and citizens responsible for high emissions, along with the new generations, other species and ecosystems. Countries with low emissions of greenhouse gases are, paradoxically, especially vulnerable to the effects of global warming. Africa accounts only for $3 \%$ of $\mathrm{CO} 2$ emissions [16], and 36 of the 50 countries that suffer most from climate change are on the continent. That is, $72 \%$ of the 50 most affected countries are Africans [17]. Africa bears the main affliction of global warming (Ruiz-Cabrera, 2017).

\section{d) To favor the debate on the change in three engines:}

The IPCC sees economic growth and population growth as the main drivers of climate change. If we break them down a bit more we can consider that among these engines are the population growth, the production and consumption model, and the energy model. It is important the debate in the transformation of each one.

- Population growth: The UN report "Population projections of the United Nations" indicates that the population will exceed 11 billion in 2100 . The world population will increase from the current 7.3 billion people to 9.7 thousand millions in 2050 and 11.2 billion by the end of the century [18]. Ideological and religious motives have had a heavy weight in claudication or little attention to this engine, which needs to be reversed. 
- Model of production and consumption: Media can encourage a cultural pattern of production and consumption without limits or otherwise another that question it and promote sustainability. According to the Worldwatch Institute (WWI 2010), the vast majority of media currently reinforce a consumer cultural pattern -through advertising [19], product sales and much of its content [20]- although efforts are being made worldwide to take advantage of its extraordinary possibility and potential to promote sustainable cultures (WWI 2010: 285). Another interesting debate may be whether the carbon markets is compatible or not with the required reduction.

- Energy model: The energy supply sector is the largest contributor of greenhouse gas emissions globally in 2010 (IPCC, 2014b: 7). It is on this motor that has focused the greatest interest in the Paris Agreement. Despite this, the energy model is not the only aspect to consider for a cultural change [21].

\section{e) Check the tuning between the objectives set out and the committed contributions of the Paris Agreement}

There is an inconsistency between the objectives and the commitments made in the French capital (FernándezReyes, 2016a: 112). At the same time, the pace of human impact continues to increase in the climate system [22]. It is necessary to analyze the level of responsibility/vagueness of national, political, economic and social commitments, as well as the accuracy of the scheduled calendar and revisions. Given the nature of the associated risk of climate change, it is justified to recover the journalistic function of "guard dogs" for the common good. There are guard dogs of the great interests within the large media structures. Structures that, as professor Reig explains, the stronger they are, the more they limit the media because of the pressures they receive and the self-censorship imposed by the interests they have in their backside, invisible to almost everyone [23]. In the society of the big show the invitation is to connect and consume (Berenguer, 2002: 7-8). Meanwhile, poor countries are already paying a brutal price for climate change [24].

The climate movement has acquired a remarkable dimension. It has been a decisive driver of the climatic objective being lowered to $1.5^{\circ} \mathrm{C}$ [25]. It is an excellent social agent to denounce the inconsistency of the commitments acquired today and will keep pointing out the heroic or the villainous [26] in action initiatives or climate inaction. This climate movement is liberated from the political interests of each country, as well as business interests, so that their claims for the common good have a more refined ethical weight than other voices. Together with the scientific field is an attractive framework and source for the media.

\section{f) Prioritizing attention on mitigation and transformational adaptation}

Adaptation and mitigation are two complementary strategies for responding to climate change. Both responses can reduce and manage the risks of climate change. The IPCC considers the responses of mitigation and adaptation, subsequently neglecting the role of avoidance and restoration [27]. To achieve the objectives set out in the Paris Agreement, we observe the specific weight of mitigation because it has a particularly strong potential. Article 7.4 of the Agreement states: "The Parties recognize that the current need for adaptation is considerable, that an increase in mitigation levels may reduce the need for additional adaptation efforts". The earlier the mitigation efforts are made, the more likely it will be to maintain the temperature rise "well below $2^{\circ} \mathrm{C}$ " or " $1.5^{\circ} \mathrm{C}$ " and less adaptation will be required. "Delayed mitigation measures may limit future climate resilient trajectories in the future" (IPCC, 2014b: 32).

Mitigation and adaptation are complementary in a complexity of interactions. However, there is a risk of overpredominance of adaptation, insofar as it allows to continue with the production and consumption model, while mitigation delays it. It may be opportune to be attentive to a possible displacement of negationism and skepticism towards adaptationism, deformation of adaptation in response to the maintenance of the status quo.

Adaptation can be progressive or transformational, depending on whether the virulence of the changes is smooth or strong. We consider, in a special way, to focus on the transformational adaptation by the trends of emissions to date and to be defined in the systemic scope.

\section{g) Report on the multiplier effect and non-linearity of climate change}

Until now we do not know the existence of any study that deepens in the factor of multiplication of the 
temperature increase in the degrees centigrades in Spain, which depends on numerous circumstances. But it can be said that the increase in temperature by climate change in Spain roughly doubles the global, although that number varies between different seasons (especially winter and summer), altitudes-latitudes and different temporal reaches.

The models contemplate a global warming linearity that does not take into account the points of inflection [28]. It is good not to forget the references to sudden or abrupt changes that have been appearing in all IPCC reports:

I IPCC Report: “They can be abrupt, not gradual,” p. 62 General Summary (1990)

II IPCC Report: "There may be nonlinear surprises," p. 6 Second Assessment (1995)

III IPCC Report: "Sudden, non-linear and severe results", p.16 Synthesis (2001)

IV IPCC Report: "Abrupt and irreversible long-term changes," p. 78 Synthesis (2007)

V IPCC Report: “Abrupt changes”, pp. 13 and 16 Synthesis (2014)

\section{h) To favor the debate of the change of civilizatory model before the model of hegemonic growth unsustainable}

Numerous studies on the coverage of climate change in Spain show the prevalence of an imbalance between information on impacts, attribution of responsibilities and solutions, with greater attention to impacts than the other two vectors. If we focus on solutions, we believe that the debate on the need for a change in the cultural model is necessary: to move from a growing and unlimited consumerist society to a society with sustainability as its axis. If so, this debate is hardly present in the structure of the media and in its hegemonic discourse. And the challenge is impressive (Fernández-Reyes, Teso and Piñuel, 2013). Nor is it present in the scientific framework, which is increasingly aiming to question the validity of the prevailing social system, based on the goal of unsustainable growth. "But this is a discourse that is not yet hegemonic and still is not even a canonical discourse in the scientific community" (Piñuel, 2016: 27).

The land is fertilized for a great cultural change, a new paradigm, with new lifestyles. It is necessary to make a jump towards good living, recognizing the limits of the planet and the need to reduce the impact. "Narrative strategies are needed that promote social change towards a new paradigm" (Teso, 2015).

\section{i) Disseminating the tools: carbon footprint and the ecological footprint}

The tools of the ecological footprint [29] and the carbon footprint [30] are two valid instruments for the analysis of the reality of the impact of the human being linked to its responsibility. Within the ecological footprint, the carbon footprint has become particularly important: if in 1961 it accounted for $43 \%$ of the ecological footprint, in 2012 it accounted for $60 \%$ [31]. Most of the years, there have been an upward trend in the carbon footprint within the ecological footprint. The main cause has been the burning of fossil fuels: coal, oil and natural gas.

At present, the human species needs more than one planet and a half to maintain existing demand. In 2013, humanity needed the equivalent biocapacity of 1.7 Earth planets to meet its demand [32]. However, it is opportune to differentiate between the most emitting countries and the per capita emissions. This shows a very different responsibility.

\section{Conclusion and discussion}

Climate change is acquiring a special aspect of the global emergency, so that communicative practice assumes a great social role in tackling this challenge. Science showed clear conclusions about climate change. The $\mathrm{V}$ IPCC Report (2014) confirmed that the climate system's warming is clear, unequivocal, and has already generated impacts on all continents and oceans, and that mitigation and adaptation will be necessary to avoid harmful climatic impacts. The Paris Summit, in December 2015, had the unprecedented presence of 150 heads 
of State, which shows the level of recognition of the challenge. On the other hand, sustainability and climate change were prominently included in the UN priorities in the Sustainable Development Objectives for the years 2015-2030.

Despite the scientific and political recognition of the severity of climate change, the problem cannot be reversed. What's more, it continues to accentuate [33]. Stopping climate change becomes one of the main challenges of the human species in this historical context. Overshoot and the possibility of environmental collapse on the horizon, seen from the systemic analysis, require a readjustment that can translate into a cultural change. We embark on the greatest threat of the human species. We are living a decisive historical moment, a colossal challenge not only for the present civilization but for the species and the rest of species "companions of travel". The emission curve has to be modified in a very short time. This justifies the investigation of journalism in transition as a social function of the media and as a legitimate requirement of society.

The quest for journalism in transition aims to take shape in a multitude of different scenarios, motivating a continuous and creative reelaboration of concepts and practices, with a multisectoral and multiscale approach to climate change. Even so, it is nothing new. In fact, it has been brewing for some time in certain communicative practices. If there is something new under the sun, it is the degree of planetary emergency that the processes of overextending climate change signal us, which motivate us to be more justified to advance by this type of journalistic exercise. It is for this reason that we consider that the search for journalism in transition is one of the keys to the research and the journalistic exercise of our time in order to meet the Paris climate objective, the Sustainable Development Objectives and the risks of climate change of which science is warning.

\section{Bibliographic references}

BERENGUER JANÉ, MARIANO (2002). Introducción al Periodismo Científico. Sevilla: Padilla Libro Editores \& Libreros

BOYKOFF M.T., MARCO D., RANDALLS S. (2010). "Discursive stability meets climate instability: a critical exploration of the concept of "climate stabilization" in contemporary climate policy". Global Environ Change 2010, 20: 53-64. Editors: J. Barnett, D. Conway, L. Lebel, M. New, K. Seto

MINISTERIO DE AGRICULTURAALIMENTACIÓN Y MEDIO AMBIENTE (2014). Cambio Climatico: Mitigación. Guía resumida del Quinto Informe de Evaluación del IPCC, Grupo de Trabajo III

CAMBIO GLOBAL EN ESPAÑA 2020/2050. (2011). Energía, Economía y Sociedad Asturias: Ed. CCEIM y Fundación Conama

CAPRA, F. (1982). El punto crucial. Ciencia, sociedad y cultura naciente. Barcelona: Integral

CRUTZEN, P. J. y STOERMER, E. F. (2000). “The Antropocene” Global Change Newsletter, 41. Stockholm: IGBP

DUARTE, CARLOS M. (coord.), (2006). Cambio global. Madrid : CICS

FERNANDEZ-REYES, R., TESO, G. y PIÑUEL, JL. (2013). "Propuestas de soluciones en la comunicación del cambio climático", México: Razón y Palabra 84

FERNANDEZ-REYES, ROGELIO (2010). "Reconocimiento y cuestionamiento mediático del cambio climático en España”. Contribuciones a las Ciencias Sociales, diciembre

FERNANDEZ-REYES, ROGELIO (2016a). "El Acuerdo de París y el cambio transformacional”, Papeles de relaciones ecosociales y cambio global $n^{\circ} 132$, pp. 101-114. Madrid : FUHEM Ecosocial

FERNANDEZ-REYES, ROGELIO (2016b). En búsqueda de un periodismo en transición ante el cambio climático. México : Razón y Palabra 93, pp 776-806 
FERNANDEZ-REYES, ROGELIO (2017) Spain Newspaper Coverage of Climate Change or Global Warming, 2000-2017. Universidad de Sevilla, http://sciencepolicy.colorado.edu/media_coverage/spain, visited on June 1 2017

HERRERO, Y., CEMBRANOS, F. y PASCUAL, M. (coords.) (2011). Cambiar las gafas para mirar el mundo. Una nueva cultura de la sostenibilidad. Madrid: Libros en Acción

HOPKINS, R. (2008). The Tansition Handbook. From oil dependency to local resilience. Totnes: Green Books.

IPCC (2013). AR5 Working Group I. Climate Change 2013: The Physical Science Basis.

IPCC (2014a). AR5 Working Group II. Climate Change 2014: Impacts, Adaptation, and Vulnerability

IPCC (2014b) AR5 Working Group III. Climate Change 2014: Mitigation of Climate Change

IPCC (2014c). AR5. Informe de Síntesis. Cambio climático 2014

MEADOWS, DONELLA Y RANDERS, JORGEN Y MEADOWS, DENNIS (2006). Los límites del crecimiento: 30 años después. Barcelona: Galaxia Gutenberg

MEIRA, PABLO ÁNGEL (2015). "De los Objetivos de Desarrollo del Milenio a los Objetivos para el Desarrollo Sostenible: el rol socialmente controvertido de la educación ambiental". Educació Social. Revista d'Intervenció Socioeducativa, 61, p. 58-73 Barcelona: Pere Tarrés Editores

MORIN, EDGAR (2011). La Vía. Para el futuro de la humanidad. Barcelona: Paidós

NOVO, MARÍA (2016). "La necesaria transición personal: no se cambia la vida sin cambiar la propia vida", en PRATS, Fernando, Herrero, Yayo y Torrero, Alicia La gran encrucijada. Sobre la crisis ecosocial y el cambio de ciclo histórico. Madrid: Libros en Acción

PIÑUEL, José Luis (2016), "Discursos mediáticos y representaciones sociales sobre el cambio climático" Redes.com $n^{\circ} 13$

RASKIN, Paul et al (2006). La Gran Transición: la promesa y la atracción del futuro. Santiago de Chile : CEPAL

REES, W. y WAKKERNAGEL, M. (1996). Our Ecological Footprint. Reducing Human Impact on Earth. Canada : New Society Publishers, Traducido al español en Rees, W. y Wackernagel, M. (2001). Nuestra huella ecológica. Reduciendo el impacto humano sobre la Tierra, Santiago de Chile: LOM ediciones

REIG, RAMÓN (1994). La mente global. Un estudio sobre estructura y análisis de la información. Madrid: Libertarias/Prodhufi

REIG, RAMÓN (1998). Medios de comunicación y poder en España. Prensa, radio, televisión y mundo editorial. Barcelona: Paidós Papeles de Comunicación 21

RIVILLO, JESÚS (2015). Refugiados climáticos y el cambio social en territorios frontera. Tesis doctoral. Facultad de Ciencias de la Información de la Universidad Complutense de Madrid

ROCKSTRÖM et al., (2009). “A safe operating space for humanity”, Nature 461: 472-475. United Kingdom: Nature Publishing Group

ROJO, T. y MAESTRE, J. (2005). "El papel de los Medios de Comunicación en el cambio social ¿cronista o protagonista?”, en GOMEZ y MENDEZ, José Manuel (ed. lit.), Entre la formación y la comunicación, pp. 250-277

RUIZ-CABRERA, SEBASTIÁN (2017). “A fuego lento. Efectos del cambio climático en Africa”, revista Pueblos n 73. Madrid: Paz con dignidad

TESO, G (2015). Comunicación y representaciones del cambio climático: el discurso televisivo y el imaginario de los jóvenes españoles. Tesis doctoral, Facultad de Ciencias de la Información de la Universidad Complutense 
de Madrid.

WORLD WATCH INSTITUTE (2010). La situación del mundo 2010: Cambio cultural. Del consumismo hacia la sostenibilidad. Barcelona: Icaria

[01] Global change is understood as "the set of environmental changes affected by human activity, with special reference to changes in the processes that determine the functioning of the Earth system" (Duarte, 2006: 23)

[02] The definition of the Framework Convention on Climate Change adopted at the 1992 Rio Summit and in force in the negotiations: "climate change that can be attributed directly or indirectly to human activities that change the composition of the Global atmosphere and thus disturb the natural variability of the climate "

[03] The term transition has been used by numerous authors, such as Capra (1982), Meadows et al. (2006). Raskin et al (2006) or Hopkins (2008)

[04] United Nations Framework Convention on Climate Change

[05] World Resources Institute, Estimates for Global Temperature Rise with INDCs above pre-industrial levels.

[06] http://www.un.org/sustainabledevelopment/es/objetivos-de-desarrollo-sostenible/, consultado el 30 de mayo de 2017

[07] One might ask: Development of what? For whom? How much is too much? In a world with great inequalities in a convergence framework where only the poorest countries can have justified an increase in the impact of the ecological footprint while the rich countries reduce their

[08] As Meadows et al (2006: 397) argue: "it would be safer, and probably preferable, to learn to live a satisfactory life at some distance from the estimated limits of the planet, rather than aspire to reach the maximum physically possible"

[09] http://www.lavanguardia.com/natural/clima/20151212/30753432839/varapalo-de-los-cientificos-aldocumento-de-paris.html, accessed May 30, 2017

[10] The Observatory of Mauna Loa Observatory counted on 21 May 2017 a concentration of 410.09 ppm of $\mathrm{CO} 2$, a figure that is far from the 280 that existed before the industrial era

[11] As for the thematic agenda of a journalism in transition on climate change is important the disposition of the journalist and the media. Normally environmental journalists are the ones who introduce sensitivity for this matter, despite the reluctance of communicative structures. In a way they are, many times without pretending, cultural pioneers

[12] It is necessary to "change glasses to look at the world" and try from another perspective, that of sustainability and equity, such as energy, economics, technology, information itself, virtual reality, mobility, growth, Human needs, the world of work, education, gender, advertising, etc. (Herrero et al, 2011)

[13] IPCC (2014) Cambio Climático: Mitigación. Guía resumida del Quinto Informe de Evaluación del IPCC, Grupo de Trabajo III. Ministerio de Agricultura Alimentación y Medio Ambiente, p. 7

[14] The search for a unanimous consensus has reduced the level of the drafts to such illogical points as this one and makes it necessary, in the present and in the future, that any dissent overturns the measures that are required not to cross the margins of Security indicated by science.

[15] El cambio climático fuerza ya a decenas de millones de personas a migrar.

http://www.efeverde.com/noticias/refugiados-climaticos-migrar/, accessed June 16, 2017)

[16] http://www.efeverde.com/noticias/refugiados-climaticos-migrar/, accessed May 30, 2017 
[17] Ségoléne Royal, in the COP 22, http://www.un.org/sustainabledevelopment/blog/2016/11/the-eyes-of-theworld-are-upon-us-chair-of-un-conference-says-as-new-round-of-climate-talks-opens/, accessed May 30, 2017

[18] http://www.oei.es/divulgacioncientifica/?La-poblacion-mundial-superara-los, accessed May 30, 2017

[19] As the Global Change in Spain report (2011: 223) indicates, advertising is "a powerful mechanism for shaping social behavior that promotes direct consumption patterns, with its indirect energy derivations, far from responsible behavior. Due to its presence, persistence and intensity, the influence of consumer advertising has an enormous capacity to counteract the energy saving messages that eventually appear. It would require a very drastic and profound change in this field to neutralize its influence in the promotion of consumerism"

[20] As Professor Reig points out, "Information in general and journalistic in particular is that, unlike advertising information, it persuades and constructs realities in the recipient without saying it, without acknowledging it" (1994: 16)

[21] Since the Fourth IPCC Report (2007), "many renewable energy technologies have demonstrated substantial improvements in their performance and cost reduction, and a greater number of renewable energy technologies have reached a maturity level to allow significant scale deployment "(IPCC, 2014b. Op.cit., p.69). But can the current level of energy consumption be maintained? There are parameters of another paradigm that are not taken into account by the IPCC. We believe that efficiency and technology are not enough. It would have to add a will of material and energetic decrease, of a cultural transformation, of shared sobriety, of a paradigm shift with sustainability as axis

[22] NOAA Global Analysis for 2016 https://www.co2.earth/ Accessed on June 2017

[23] "It is necessary to know who speaks to us through the informational messages and the power that supports the media that accompany us daily, and in which we deposit our trust many times, since this power structure influences decisively that The messages have a content or another, an intention or another "(Reig, (1998). Medios de comunicación y poder en España. Prensa, radio, televisión y mundo editorial. Barcelona: PaidósPapeles de Comunicación 21 p. 11

[24] Kumi Naidoo (2009), Director of Greenpeace in El País, November 16, 2009

[25] The Agreement invites the Intergovernmental Panel on Climate Change to submit in 2018 a special report on the effects of global warming of $1.5^{\circ} \mathrm{C}$ on pre-industrial levels and the corresponding paths to be followed by emissions Global greenhouse gas emissions. It is a good opportunity to focus attention on what this objective means

[26] In recent months we are witnessing how President Donald Trump is generating more media coverage, appearing with climatic "villain" connotations for his political decisions

[27] In the field of environmental and climate policies there are four consolidated and complementary approaches: mitigation, adaptation, avoidance and restoration, in El Medio Ambiente en Europa. Estado y perspectiva 2015, p. 15

[28] The main threat James Hansen considers "the risk that ice sheets may suffer a forcing in this century that is well above the ranges we consider natural," in http://www.elespanol.com/ciencia/ecologia/20170613/223478220_0.html

[29] A tool used to determine the ecologically productive area of land and sea required to provide all the material resources and energy consumed, and also to absorb all the waste produced by a given population and at the current technological level, wherever Whether this area is found (Rees and Wackernagel, 1996)

[30] Amount of greenhouse gases emitted into the atmosphere from the activities of production or consumption of goods and services of humans 
[32] http://www.footprintnetwork.org/, accessed May 30, 2017

[33] https://www.co2.earth/co2-acceleration, accessed May 30, 2017

- Recibido: 15 de junio de 2017

- Aceptado: 30 de junio de 2017

Ámbitos. Revista Internacional de Comunicación, n.37, edición de verano, 2017. 